\title{
Physicochemical and Functional Properties of Full Fat and Defatted Ackee (Blighia sapida) Aril Flours
}

\author{
Veronica M. Dossou, Jacob K. Agbenorhevi*, Francis Alemawor, Ibok Oduro \\ Department of Food Science and Technology, Kwame Nkrumah University of Science and Technology, Kumasi, Ghana \\ *Corresponding author: jkagbenorhevi.cos@knust.edu.gh
}

Received October 28, 2014; Revised November 12, 2014; Accepted November 17, 2014

\begin{abstract}
The pulp/arils of ackee (Blighia sapida) were oven/freeze dried, processed into full fat and defatted flours and analyzed for some physicochemical and functional properties. Moisture, crude fat, crude protein, crude fibre, ash and carbohydrate content of the flours ranged from 4.83-7.30\%, 21.42-59.54\%, 11.54-23.00\%, 3.83-4.08\%, $8.45-9.05 \%$ and $15.13-42.48 \% \mathrm{db}$, respectively. Potassium (462.21-968.29 mg/100 g) and zinc (1.99-3.55 mg/100 g) were the most and least abundant minerals, respectively. Functional properties ranged from 24.09 to $39.45 \%$ solubility, 11.03 to $23.02 \%$ swelling power, 111.75 to $139.57 \%$ oil absorption capacity, 4.33 to $5.67 \%$ foaming capacity, 76.34 to $84.35 \%$ foam stability, 61.67 to $69.17 \%$ emulsion capacity and 5.83 to $46.67 \%$ emulsion stability. Generally, defatted flours had higher values for proximate composition and functional properties than the full fat flours. Oven dried ackee aril flours had higher emulsion activity and stability suggesting their potential application in foods such as, mayonnaise, yogurt, ice-cream, sausages and processed meats.
\end{abstract}

Keywords: Ackee (Blighia sapida), ackee arils, Blighia sapida, physicochemical properties, functional properties, ackee flour, defatted flour

Cite This Article: Veronica M. Dossou, Jacob K. Agbenorhevi, Francis Alemawor, and Ibok Oduro, "Physicochemical and Functional Properties of Full Fat and Defatted Ackee (Blighia sapida) Aril Flours." American Journal of Food Science and Technology, vol. 2, no. 6 (2014): 187-191. doi: 10.12691/ajfst-2-6-3.

\section{Introduction}

The over dependence on only few plant species for food has made food security a challenge and a major concern in the world. This has led to several calls for investigation into alternative food sources to improve food security worldwide. Conservation, domestication and utilization of many indigenous wild fruit and vegetable species can contribute to hunger reduction and improved nutrition and health [1]

Ackee (Blighia sapida) is a fruit tree, originating from the Guinean forests of West Africa, where it is noted particularly for its medicinal and aesthetic values. The ripe ackee fruit arils are edible and can be eaten fresh, dried, fried, boiled, roasted or made into sauce or soup. In Benin, the dried ackee arils and ackee soap, made from the ash of fruit pods and seeds, are traded in local markets providing substantial revenue to farmers and traders who are mostly women [1,2]. Ackee has gained recognition as 'Jamaica's National Fruit' with the fruit arils being the primary component of the national dish (ackee and codfish), where it is boiled in brine and cooked with onions, tomatoes and codfish [3].

Jamaican vomiting sickness or toxic hypoglycemic syndrome, caused by the high amounts of hypoglycin A and $\mathrm{B}$ in unripe fruits was a major drawback to the exploitation of ackee arils for food [3,4]. However, exposure of the fruit arils to the sun at full maturity, when fruit pods split open, reduces the hypoglycin A and B contents of the arils to negligible amounts, making them safe for consumption [5,6].

Ackee arils are generally reported to be rich in potassium, magnesium, calcium and sodium but low in phosphorus and zinc with potassium being the most abundant mineral. Previous studies have shown that ackee arils have high oil content, comparable to those of peanuts, rapeseed and sunflower seeds and higher than that of soybeans $[7,8,9]$. Although aspartic acid was undetected, all essential amino acids, with arginine being the predominant amino acid, were reportedly present in ripe ackee arils [6]. Ackee arils have been reported to be rich in linoleic, oleic, palmitic and stearic fatty acids which are known to help reduce the risk of coronary heart diseases when included in the diet. Oleic acid was the predominant fatty acid in the mature arils. The ratio of unsaturated to saturated fatty acids in matured ackee arils varied from 1.23 to 3.26 in the arils of both cheese and butter varieties $[10,11]$. Oven dried ackee aril flour has been reported to have some superior functional properties to soy flour, soyprotein concentrate, wheat flour, A. breviflorus benth seed flour, pigeon pea, lupin seed and winged bean flours [7].

Ackee is poorly exploited as food in Ghana and many parts of West Africa. Thus, several tonnes of ackee arils go waste annually in the sub-region. Commercial processing of ackee is limited to drying (Benin) and boiling in brine (Jamaica). Dried arils have short shelf stability of about two weeks [1] while secondary or tertiary ackee products for increased application in food 
are limited. Flours are major ingredients in industrial food processes. Ackee flours could find several useful applications in the food industry. Defatting could contribute to improved quality properties and shelf stability of the flours. Also, a study of the effect of drying method on dehydrated food products is necessary for the development of a product with optimum quality for the food industry.

The objective of the present research, therefore, was to investigate the physicochemical and functional properties of full fat and defatted ackee aril flours and the effect of the drying method and defatting on these properties of the ackee aril flours.

\section{Materials and Methods}

\subsection{Materials}

Distilled water, deionized water and all chemicals used were of analytical grade. Self ripened (i.e., split opened yellow-red skin) ackee fruits were harvested, using a sickle, from trees at the Crops Research Institute of Ghana- Fumesua and the Presbyterian Primary and Junior High School at Bantama in Kumasi-Ashanti Region of Ghana. The fruit arils were separated from the pink membranes and seeds and cleaned by washing with copious amount of water. About $2 \mathrm{~kg}$ of cleaned arils was dried for 72 h using a vacuum freeze dryer (YK 115-50, True Ten Industrial Co. Ltd, Taiwan) and another $2 \mathrm{~kg}$ of arils was dried at $50^{\circ} \mathrm{C}$ for $72 \mathrm{~h}$ in a Beveilinging Conventional Oven Dryer (DMV 1250, Holland). After drying, the arils were milled into flour using a Binatone kitchen grinder (model: BLG 402), passed through a 1 $\mathrm{mm}$ mesh sieve and separated into two equal portions. One portion was defatted by soaking in petroleum ether in a ratio of 1:3 (w/v) for $120 \mathrm{~h}$ with periodic agitation. After defatting, the mixture was filtered with a cheese cloth to remove the liquid filtrate and obtain the defatted flour. The defatted flour was dried for $2 \mathrm{~h}$ at ambient temperature in a fume hood and packed in airtight polyethylene bags and stored in a freezer at $-18{ }^{\circ} \mathrm{C}$ for further analysis.

\subsection{Proximate Composition Determination}

The proximate compositions (moisture, ash, crude protein, crude fat, crude fibre and carbohydrate) of the ackee aril flours were determined using the methods described by the Association of Official Analytical Chemists [12]. Carbohydrate content was determined by difference while percentage nitrogen was determined by the macro-Kjeldahl method and converted to crude protein content by multiplying with factor 6.25 .

\subsection{Mineral Composition Analysis}

Calcium (Ca), magnesium (Mg) and zinc ( $\mathrm{Zn})$ contents were determined using Atomic absorption spectrophotometer (210VGP, Buck Scientific, USA), sodium $(\mathrm{Na})$ and potassium $(\mathrm{K})$ contents were determined using a flame photometer (Jenway PFP7), and phosphorus (P) content was determined using a spectrophotometer (Lemfield Spectrulab 23A).

\subsection{Bulk Density Determination}

Bulk Density was determined according to the method described by Maninder et al. [13]. Hausner ratio was determined as a ratio of the tapped bulk density to the loose bulk density of the flour.

\subsection{Functional Properties Determination}

The modified method of Medcalf and Giles [14] was used to determine water and oil absorption capacities of the ackee aril flour samples while foaming capacity, foaming stability (after $5 \mathrm{~h}$ ), emulsion activity and emulsion stability were measured according to the method described by Jitngarmkusol et al. [15]. The solubility and swelling power (SP) of ackee aril flour were determined using the method described by Leach et al., [16].

\subsection{Statistical Analysis}

Data was reported as averages of triplicate or duplicate determinations and analyzed using Analysis of Variance (ANOVA), Tukey's test at 5\% level of significance, to determine significant differences among samples. Correlation test (Pearson) between proximate composition and functional properties was also performed. The statistical package used was IBM SPSS Statistics version 20 (IBM Corp, Armonk, NY).

\section{Results and Discussion}

\subsection{Proximate Composition of Ackee Aril Flours}

The moisture content of the ackee aril flour samples were $4.83 \%$ for oven-dried full fat (ODFF), $5.20 \%$ for freeze-dried full fat (FDFF), $5.12 \%$ for oven-dried defatted (ODDF) and $7.30 \%$ for freeze-dried defatted (FDDF) flours, respectively. The crude fat, protein, ash, crude fibre, carbohydrate and calculated metabolizable energy values of the flours are presented in Table 1 . The ash and carbohydrate contents recorded were higher than previously reported in literature for ackee arils $[7,8,9]$.

Table 1. Proximate Composition of Ackee Aril Flours in \% dry basis

\begin{tabular}{ccccc}
\hline Parameter & ODFF & FDFF & ODDF & FDDF \\
\hline Crude fat & $59.54 \pm 0.28^{\mathrm{a}}$ & $54.43 \pm 2.35^{\mathrm{b}}$ & $25.82 \pm 2.75^{\mathrm{c}}$ & $21.42 \pm 0.9^{\mathrm{c}}$ \\
Ash & $8.99 \pm 0.47^{\mathrm{a}}$ & $8.45 \pm 1.19^{\mathrm{a}}$ & $8.68 \pm 0.42^{\mathrm{a}}$ & $9.05 \pm 0.01^{\mathrm{a}}$ \\
Crude Fibre & $4.08 \pm 0.16^{\mathrm{a}}$ & $3.83 \pm 0.01^{\mathrm{a}}$ & $3.88 \pm 0.18^{\mathrm{a}}$ & $4.05 \pm 0.36^{\mathrm{a}}$ \\
Crude & $12.26 \pm 0.38^{\mathrm{a}}$ & $11.54 \pm 0.20^{\mathrm{b}}$ & $22.04 \pm 0.16^{\mathrm{c}}$ & $23.00 \pm 0.19^{\mathrm{d}}$ \\
Protein & & & & \\
Carbohydrate & $15.13 \pm 0.96^{\mathrm{a}}$ & $21.75 \pm 3.55^{\mathrm{b}}$ & $39.58 \pm 3.11^{\mathrm{c}}$ & $42.48 \pm 1.20^{\mathrm{c}}$ \\
CME & 2668.50 & 2579.99 & 2002.88 & 1905.71 \\
$(\mathrm{~kJ} / 100 \mathrm{~g})$ & $\pm 7.17^{\mathrm{a}}$ & $\pm 32.15^{\mathrm{b}}$ & $\pm 49.46^{\mathrm{c}}$ & $\pm 13.37^{\mathrm{d}}$ \\
\hline
\end{tabular}

Values in a row with different letters in superscript are significantly different $(\mathrm{p}<0.05)$.

CME: Calculated Metabolizable Energy.

Defatting yielded about $56.63 \%$ and $60.66 \%$ reduction in the fat contents of the ackee flours, yielding low-fat ackee flours with crude fat contents of $21.42 \%$ (FDDF) and $25.8 \%$ (ODDF). The crude fibre contents of ackee aril flours were higher than in macadamia flours $(2.65 \%$ to $3.77 \% \mathrm{db})$ as well as whole sesame seed and defatted sesame flours (1.89 - 3.64\%) [15,17]. The protein contents of the defatted ackee flours (ODDF and FDDF) compared favourably with those of many known legume flours; cowpea (24.1\%), horse gram (22.5\%), chickpea (23.7\%), 
pigeon pea (19.9\% - 24.0\%) and field pea (25.6\% - 26.2\%) $[13,18]$.

Defatted ackee aril flours recorded significantly higher carbohydrate contents than their corresponding full fat flours ( $<<0.05$ ). The calculated metabolizable energy (CME) of the full fat ackee aril flours (ODFF and FDFF) were higher than reported for sun-dried ackee arils [9]. Fat provides more energy per gram than carbohydrates or proteins in the diet. Therefore, a reduction in the fat content of food translates into reduced energy content of the food as seen with the CME values reported for the defatted ackee aril flours. Defatted ackee aril flours may serve as a better dietary option for people who want to reduce weight than the dried ackee arils.

\subsection{Mineral Composition of Ackee Aril Flours}

Results of mineral composition of the ackee aril flours (Table 2) showed potassium to be the predominant mineral, ranging from 425.10 to $981.78 \mathrm{mg} / 100 \mathrm{~g}$ while zinc was the least mineral, ranging from 1.95 to 3.58 $\mathrm{mg} / 100 \mathrm{~g}$. Similar trends have been reported for dried ackee arils $[7,8,9]$. Defatting significantly increased the concentration of minerals, resulting in defatted flours (ODDF and FDDF) having higher mineral contents that the full fat flours (ODFF and FDFF). Ca, K and $\mathrm{Mg}$ of the ackee aril flours were higher than reported for jack bean, pigeon pea and cowpea [19].

Table 2. Mineral Composition of Ackee Aril Flours

\begin{tabular}{ccccc}
\hline $\begin{array}{c}\text { Mineral } \\
(\mathrm{mg} / 100 \mathrm{~g})\end{array}$ & ODFF & FDFF & ODDF & FDDF \\
\hline $\mathrm{Ca}$ & $160.00 \pm 0.0^{\mathrm{a}}$ & $200.00 \pm 0.0^{\mathrm{b}}$ & $240.00 \pm 0.0^{\mathrm{c}}$ & $240.00 \pm 0.0^{\mathrm{c}}$ \\
$\mathrm{Mg}$ & $240.00 \pm 0.0^{\mathrm{a}}$ & $185.00 \pm 7.07^{\mathrm{b}}$ & $390.00 \pm 0.0^{\mathrm{c}}$ & $500.00 \pm 14.14^{\mathrm{d}}$ \\
$\mathrm{P}$ & $152.43 \pm 0.00^{\mathrm{a}}$ & $152.43 \pm 4.15^{\mathrm{a}}$ & $222.78 \pm 8.29^{\mathrm{b}}$ & $297.52 \pm 2.07^{\mathrm{c}}$ \\
$\mathrm{K}$ & $475.71 \pm 0.0^{\mathrm{a}}$ & $425.10 \pm 14.31^{\mathrm{a}}$ & $804.66 \pm 35.79^{\mathrm{b}}$ & $981.78 \pm 0.0^{\mathrm{c}}$ \\
$\mathrm{Zn}$ & $1.95 \pm 0.05^{\mathrm{a}}$ & $2.08 \pm 0.02^{\mathrm{b}}$ & $2.9 \pm 0.00^{\mathrm{c}}$ & $3.58 \pm 0.02^{\mathrm{d}}$ \\
$\mathrm{Na}$ & $84.24 \pm 0.00^{\mathrm{a}}$ & $73.37 \pm 3.84^{\mathrm{a}}$ & $123.65 \pm 1.92^{\mathrm{b}}$ & $171.20 \pm 3.84^{\mathrm{c}}$ \\
\hline
\end{tabular}

Values in a row with different letters in superscript are significantly different $(\mathrm{p}<0.05)$.

\subsection{Bulk Density}

Freeze dried ackee aril flours had lower bulk densities than the oven dried flours (Table 3). This implies that FDFF and FDDF will require larger storage spaces per weight than ODFF and ODDF. Freeze dried products are reported to be more porous than air-dried products, accounting for the lower densities of the freeze-dried ackee aril flours [20]. The tapped bulk density (TBD) of the ackee aril flour samples were lower as compared to that of soy ogi flours $\left(0.7-0.84 \mathrm{~g} / \mathrm{cm}^{3}\right)$ while the loose bulk density (LBD) of the ackee flour samples were generally higher than for full fat and defatted moringa kernel flours (0.37 and $0.26 \mathrm{~g} / \mathrm{cm}^{3}$ respectively) [21,22].

Hausner ratios of ODDF and FDDF were lower than that of defatted moringa kernel flours while ODFF and FDFF had higher Hausner ratios than that of full fat moringa kernel flours [22]. Food flours/powders with good flow properties (i.e. Hausner ratio less than 1.4) facilitate their conveying, blending and packaging and thus encourage their application in industrial food manufacturing [22,23]. Due to its lower Hausner ratio,
FDDF may, therefore, be the ackee aril flour of choice for industrial food applications.

Table 3. Bulk Density of Ackee Aril Flours

\begin{tabular}{ccccc}
\hline PARAMETER & ODFF & FDFF & ODDF & FDDF \\
\hline LBD (g/mL) & $0.44 \pm 0.00^{\mathrm{a}}$ & $0.31 \pm 0.00^{\mathrm{b}}$ & $0.50 \pm 0.01^{\mathrm{c}}$ & $0.50 \pm 0.00^{\mathrm{c}}$ \\
TBD (g/mL) & $0.72 \pm 0.00^{\mathrm{a}}$ & $0.55 \pm 0.01^{\mathrm{b}}$ & $0.72 \pm 0.00^{\mathrm{a}}$ & $0.61 \pm 0.02^{\mathrm{c}}$ \\
Hausner Ratio & $1.64 \pm 0.08^{\mathrm{a}}$ & $1.78 \pm 0.20^{\mathrm{b}}$ & $1.45 \pm 0.12^{\mathrm{c}}$ & $1.21 \pm 0.03^{\mathrm{d}}$ \\
\hline \multicolumn{5}{l}{ Values in a row with different letters in superscript are significantly } \\
different (p $<0.05)$ & & \\
LBD: Loose bulk density & & & \\
TBD: Tapped bulk density & & & \\
ND: Not determined & & &
\end{tabular}

\subsection{Functional Properties of Ackee Aril Flours}

\subsubsection{Water and Oil Absorption Capacities (WAC and OAC)}

ODDF had a significantly higher WAC than FDDF (Table 4). Lower WAC was recorded for local Nigerian wheat flour (140\% - 150\%), irradiated and non irradiated cowpea flours $(110 \%-113 \%)$, and different yam flours (194\% - 207\%) [24,25,26].

The ackee aril flours recorded lower OAC (Table 4) than was previously reported for full fat ackee pulp/aril flour (131.6\%) [7]. The OAC of the ackee aril flours were comparable to cowpea (83 - 113\%) but lower than for mucuna (200 - 260) and defatted macadamia flour (305 493\%) [15,25].

\subsubsection{Foaming Capacity and Stability}

Foaming capacity (FC) and foaming stability (FS) of the ackee aril flours (Table 4) were lower than that of flours of different macadamia cultivars [15]. Although foaming capacities of flours of six mucuna cultivars were higher, the foaming stabilities after $4 \mathrm{~h}$ were lower than those of the ackee aril flour samples [27].

Table 4. Some Functional Properties of Ackee Aril Flours

\begin{tabular}{ccccc}
\hline PARAMETER & ODFF & FDFF & ODDF & FDDF \\
\hline FC (\%) & $5.67 \pm 0.58^{\mathrm{a}}$ & $5.00 \pm 1.00^{\mathrm{a}}$ & $5.67 \pm 0.58^{\mathrm{a}}$ & $4.33 \pm 0.58^{\mathrm{a}}$ \\
FS (\%) & $82.65 \pm 1.38^{\mathrm{a}}$ & $82.83 \pm 3.28^{\mathrm{a}}$ & $76.34 \pm 0.95^{\mathrm{a}}$ & $84.35 \pm 3.58^{\mathrm{a}}$ \\
(after 5 h) & & & $982.88 \pm$ & \\
WAC (\%) & ND & ND & $120.62^{\mathrm{a}}$ & $565.53 \pm 9.06^{\mathrm{b}}$ \\
OAC (\%) & $111.75 \pm 4.20^{\mathrm{a}}$ & $117.47 \pm 4.58^{\mathrm{a}}$ & $139.57 \pm 5.59^{\mathrm{b}}$ & $134.87 \pm 2.87^{\mathrm{b}}$
\end{tabular}

Values in a row with different letters in superscript are significantly different ( $\mathrm{p}<0.05)$. FC; foaming capacity; FS: foam stability; WAC: water absorption capacity; OAC: oil absorption capacity. ND: not determined.

Oven dried ackee aril flours (ODFF and ODDF) recorded higher FC than freeze dried flours (FDFF and FDDF). Partial denaturation of proteins increases their solubility and consequently foaming capacity due to the unfolding of the protein structure which allows more protein surface to be exposed and interact with the external environment [28]. Oven drying, as opposed to freeze drying, employs heat application, contributing to the partial denaturation of proteins in the sample. This probably accounted for the higher FC observed for ovendried ackee aril flours than for freeze-dried ackee aril flours.

\subsubsection{Solubility and Swelling Power}


The defatted ackee aril flours (ODDF and FDDF) had significantly higher solubility and swelling power than their corresponding full fat flours $(p<005)$ as shown in Figure 1. Swelling power of the ackee aril flours was comparable to, while solubility was higher than reported values for some cassava and sweet potato cultivars, whose swelling power and solubility ranged from $10.59 \%$ to $27.53 \%$ and 12.06 to $24.44 \%$, respectively. High swelling power and low solubility are required for formation of highly viscous and elastic gels or dough [29]. Therefore, ackee aril flours may not form very viscous and elastic gels or dough due to their high solubility and low swelling power.

\subsubsection{Emulsion Activity (EA) and Stability (ES)}

FDFF had the least EA (61.67\%) and ES (5.3\%) among the ackee aril flour samples investigated (Figure 1). Oven dried ackee aril flours (ODFF and ODDF) had significantly higher EA and ES than the freeze-dried flours (FDFF and FDDF). This could be due to thermal denaturation of proteins during oven drying which caused the proteins to unfold, exposing more hydrophobic groups to enhance emulsification. The EA of the ackee aril flours were higher, while ES were comparable to values reported for different soybean varieties grown in Ghana [30]. High emulsion activity and stability is important in food emulsions like mayonnaise, yogurts and ice-creams.

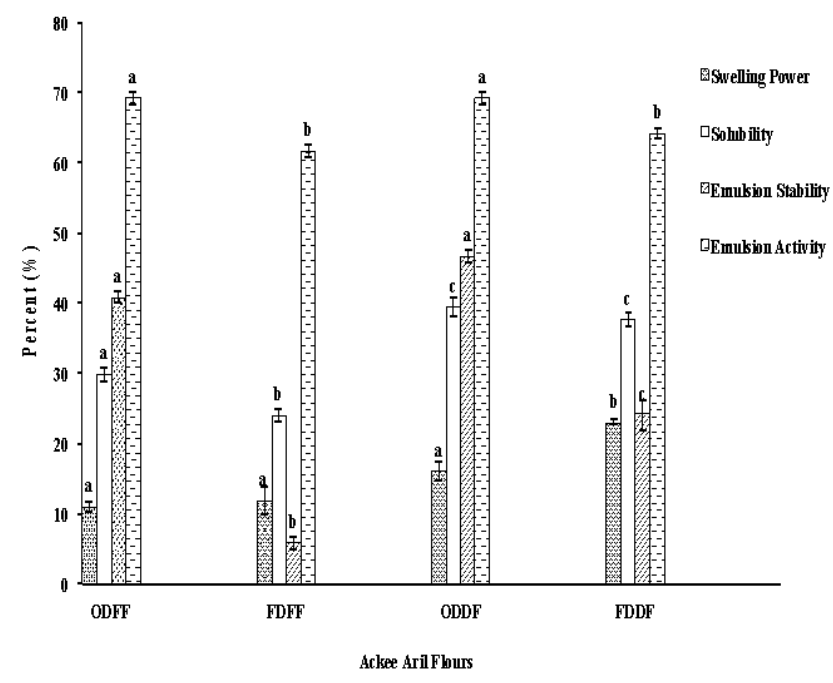

Figure 1. Functional Properties of Ackee Aril Flours

\subsection{Significance of Drying Method and/or Defatting on Ackee Aril Flour Quality}

Results of the univariate 'Test of Between-Subject Effects' (two-way ANOVA) (Table 5) indicate that the choice of drying method significantly affects $(\mathrm{p}<0.05)$ the mineral composition, functional properties as well as crude fat and carbohydrate content of the flour. Defatting of the flour imparted significant changes $(p<0.05)$ to all parameters investigated except foaming capacity, foaming stability and emulsion capacity values as well as ash and fibre contents of the ackee aril flours. There were also significant interactions between the drying method and defatting on the mineral composition (except $\mathrm{Ca}$ ) as well as swelling power, emulsion stability, tapped and loose bulk densities and Hausner ratios of the ackee aril flours.
Table 5. Significance of Treatments on Ackee Aril Flour Components and Properties

\begin{tabular}{|c|c|c|c|}
\hline \multirow[b]{2}{*}{ Parameter } & \multicolumn{3}{|c|}{ Significance of p-values } \\
\hline & $\begin{array}{l}\text { A: Drying } \\
\text { Method }\end{array}$ & $\begin{array}{c}\text { B: } \\
\text { Defatting }\end{array}$ & $\begin{array}{l}\text { Interaction: } \\
\mathrm{AB}\end{array}$ \\
\hline Fat (\%) & $*$ & $*$ & - \\
\hline Protein (\%) & - & $*$ & $*$ \\
\hline Ash (\%) & - & - & - \\
\hline Fibre (\%) & - & - & - \\
\hline Carbohydrate (\%) & $*$ & $*$ & - \\
\hline Energy (kJ/100g) & $*$ & $*$ & - \\
\hline $\mathrm{Ca}(\mathrm{mg} / 100 \mathrm{~g})$ & * & $*$ & - \\
\hline $\mathrm{Mg}(\mathrm{mg} / 100 \mathrm{~g})$ & - & $*$ & $*$ \\
\hline P (mg/100g) & $*$ & $*$ & $*$ \\
\hline $\mathrm{K}$ (mg/100g) & $*$ & $*$ & $*$ \\
\hline $\mathrm{Zn}$ (mg/100g) & $*$ & $*$ & $*$ \\
\hline $\mathrm{Na}(\mathrm{mg} / 100 \mathrm{~g})$ & $*$ & $*$ & $*$ \\
\hline WAC (\%) & $*$ & $\mathrm{x}$ & $\mathrm{x}$ \\
\hline Solubility (\%) & $*$ & $*$ & - \\
\hline Swelling Power (\%) & $*$ & $*$ & $*$ \\
\hline OAC (\%) & - & $*$ & - \\
\hline Foaming Capacity (\%) & * & - & - \\
\hline Foaming Stability (\%) & - & - & - \\
\hline Emulsion Capacity (\%) & * & - & - \\
\hline Emulsion Stability (\%) & $*$ & $*$ & $*$ \\
\hline $\begin{array}{l}\text { Tapped Bulk Density } \\
\text { (g/mL) }\end{array}$ & $*$ & $*$ & $*$ \\
\hline $\begin{array}{l}\text { Loose Bulk Density } \\
\text { (g/mL) }\end{array}$ & $*$ & $*$ & $*$ \\
\hline Hausner Ratio & $*$ & $*$ & $*$ \\
\hline
\end{tabular}

* Significant $(\mathrm{p}<0.05)$; - Not significant $(\mathrm{p}>0.05)$; $\mathrm{x}$ Not reported

Table 6. Correlation of Some Proximate Compositions and Functional Properties of Ackee Aril Flours

\begin{tabular}{cccc}
\hline Functional Properties & Fat & Protein & Carbohydrate \\
\hline \multirow{2}{*}{ Oil Absorption Capacity } & $-.904^{* *}$ & $.913^{* *}$ & $.883^{* *}$ \\
& .000 & .000 & .000 \\
Solubility & $-.861^{* *}$ & $.918^{* *}$ & $.812^{* *}$ \\
& .000 & .000 & .001 \\
Swelling Power & $-.838^{* *}$ & $.824^{* *}$ & $.829^{* *}$ \\
& .001 & .001 & .001 \\
Foaming Capacity & .285 & -.252 & -.274 \\
& .369 & .429 & .389 \\
Foaming Stability & .159 & -.128 & -.201 \\
& .622 & .691 & .531 \\
Emulsion Activity & -.049 & .183 & -.016 \\
& .880 & .568 & .960 \\
Emulsion Stability & -.243 & .379 & .164 \\
**- Correlation is significant at the 0.01 level (2-tailed) & .610 \\
*- Correlation is significant at the 0.05 level (2-tailed)
\end{tabular}

\subsection{Correlation between Components and Functional Properties of Ackee Aril Flours}

Fat content generally showed negative correlation with all functional properties except foaming capacity and stability (Table 6). Protein content, however, generally showed positive correlation with the functional properties. Correlations were significant for Oil absorption capacity, solubility and swelling power $(\mathrm{p}<0.01)$.

This implies that irrespective of the drying method employed, defatting of ackee aril flour is necessary in order to improve the proximate, mineral, density, flow and most functional properties of the ackee aril flour for food and industrial applications. Thus a reduction in the fat content will improve the functional properties of the ackee aril flours, whereas an increase in protein and carbohydrate contents will enhance the functional properties due to their generally positive correlations.

\section{Conclusion}


Inclusion of ackee arils in the diet could prove nutritionally beneficial, with defatted ackee aril flours providing significantly higher amounts of proteins and minerals than their full fat counterparts. Also, ackee arils could be exploited for vegetable oil production. Ackee aril flours possess impressive physicochemical and functional properties which could be exploited by the food industry. Defatted ackee aril flours will present ease of utilization in food industrial applications due to their good flow properties and could prove beneficial in sausages, processed meats and dough, where water absorption or binding is an important quality attribute. Oven dried ackee aril flours could prove useful in food applications requiring high emulsion activity and stability such as sausages and processed meats, mayonnaise, yogurt and ice-cream.

The choice of drying method generally affected the functional properties of the ackee aril flours, with oven drying yielding more improved flour functionality. Also, defatting significantly improved the proximate, minerals, bulk density and hausner ratios as well as functional properties of the flour, making defatting a necessary step for improving ackee aril flour for food and industrial applications irrespective of the drying method employed.

It is recommended the ackee aril flours be employed in a model food system to further explore their food application prospects.

\section{Acknowledgements}

We are grateful to Mr. Emmanuel A. Amankwah and Dr. Faustina D. Wireko-Manu for their useful suggestions.

\section{References}

[1] Ekué, M .R. M., Sinsin, B., Eyog-Matig, O. \& Finkeldey, R., Uses, traditional management, perception of variation and preferences in ackee (Blighia sapida K.D. Koenig) fruit traits in Benin: Implications for domestication and conservation, Journal of Ethnobiology and Ethnomedicine, 6 (12), 1-14, Mar. 2010.

[2] Atolani, O., Olatunji, G. A. \& Fabiyi, O. A., Blighia Sapida: The plant and its hypoglycins: an overview, Journal of Scientific Research, XXXIX (2), 15-25, Dec. 2009.

[3] Rashford, J., Those that do not smile will kill me: The ethnobotany of the ackee in Jamaica, Economic Botany, 55 (2), 190-211, Apr.-June 2001.

[4] Mitchell, S. A., Seymour, W. A. \& Ahmad, M. H., Ackee (Blighia sapida): Jamaica's top fruit, Jamaican Journal of Science and Technology, 33, 84-89, 2008.

[5] Chase Jr., G. W., Landen Jr., W. O., \& Soliman, A. G., Hypoglycin A content in the aril, seeds, and husks of ackee fruit at various stages of ripeness, Journal-Association of Official Analytical Chemists, 73 (2), 318-319, Mar-Apr 1990.

[6] Golden, K. D., Williams, O. J. \& Bailey-Shaw, Y., Highperformance liquid chromatographic analysis of amino acids in ackee fruit with emphasis on the toxic amino acid, hypoglycin A, Journal of Chromatographic Science, 40, 441-446, Sep. 2002.

[7] Akintayo E. T., Adebayo E. A. \& Arogunde, L. A., Chemical composition, physicochemical and functional properties of akee (Bilphia sapida) pulp and seed flours, Food Chemistry, 77: 333336, Aug. 2002.

[8] Howélé, O., Bobelé, N., Théodor, D. \& Séraphi, K. C., Nutritional composition studies of sun dried Blighia sapida (K. Koenig) aril from Côte d'Ivoire, Journal of Applied Biosciences 32, 1989-1994, Aug. 2010.

[9] Oyeleke, G.O., Oyetade, O.A., Afolabi F. \& Adegoke, B.M., Nutrients, antinutrients and physicochemical compositions of blighia sapida pulp and pulp oil (ackee apple), Journal of Applied Chemistry, 4 (1), 05-08, Mar-Apr 2013.

[10] Anderson-Foster, E. N., Adebayo, A. S. \& Justiz-Smith, N., Physico-chemical properties of Blighia sapida (ackee) oil extract and its potential application as emulsion base, African Journal of Pharmacy and Pharmacology, 6 (3), 200-210, Jan. 2012.

[11] Emanuel, M. A., Gutierrez - Orozco, F., Yahia, E. M. \& Benkeblia, N., Assessment and profiling of the fatty acids in two ackee fruit (Blighia sapida Köenig) varieties during different ripening stages, Journal of the Science of Food and Agriculture, 93 (4), 722-726, Mar. 2013.

[12] AOAC, Official Methods of Analysis of AOAC International, 16th edition, Association of Official Analytical Chemists, Washington, DC, 1997.

[13] Maninder, K., Kawaljit, S. S., \& Narpinder, S., Comparative study of the functional, thermal and pasting properties of flours from different field pea (Pisum sativum L.) and pigeon pea (Cajanus cajan L.) cultivars, Food Chemistry, 104, 259-267, Jul. 2007.

[14] Medcalf, D.G. \& Gilles, K.A., Wheat starches: Comparison of physicochemical properties, Cereal Chemistry, 42, 558-567, Nov. 1965.

[15] Jitngarmkusol, S., Hongsuwankul, J. \& Tananuwong, K., Chemical compositions, functional properties, and microstructure of defatted macadamia flours, Food Chemistry, 110, 23-30, Sep. 2008.

[16] Leach, H. W., McCowen, L. D. \& Schoch, T. J., Swelling power and solubility of granular starches, Cereal Chemistry, 36, 534-544, 1959.

[17] Bukya, A. \& Vijayakumar, T. P., Properties of industrial fractions of sesame seed (Sesamum indicum L.), International Journal of Agricultural and Food Science, 3 (3), 86-89, Jul. 2013.

[18] Sreerama, Y. N., Sashikala, V. B., Pratape, V. M. \& Singh, V., Nutrients and antinutrients in cowpea and horse gram flours in comparison to chickpea flour: Evaluation of their flour functionality, Food Chemistry, 131, 462-468, Mar. 2012.

[19] Olalekan, A. J. \& Bosede, F. B., Comparative study on chemical composition and functional properties of three nigerian legumes (jack beans, pigeon pea and cowpea), Journal of Emerging Trends in Engineering and Applied Sciences (JETEAS), 1 (1), 89-95, Oct. 2010.

[20] Krokida, M .K. \& Maroulis, Z. B., Effect of drying method on shrinkage and porosity, Drying Technology, 15(10), 2441-2458, 1997.

[21] Oluwamukomi, M. O., Eleyinmi, A. F. \& Enujiugha, V. N., Effect of soy supplementation and its stage of inclusion on the quality of ogi, a fermented maize meal, Food Chemistry, 91 (4), 651-657, Aug. 2005.

[22] Ogunsina, B. S., Radha, C. \& Govardhan Singh, R. S., Physicochemical and functional properties of full-fat and defatted Moringa oleifera kernel flour, International Journal of Food Science and Technology, 45 (11), 2433-2439, Nov. 2010.

[23] Barbosa-Canovas, G.V., Ortega-Rivas, E., Juliano, P. \& Yan, H., Food Powders: Physical Properties, Processing and Functionality, Kluwer Academic Publishers, London, 2005, 71-74.

[24] Iwuoha, C. I., Comparative evaluation of physicochemical qualities of flours from steam-processed yam tubers, Food Chemistry, 85, 541-551, May 2004.

[25] Abu, J. O., Muller, K., Duodu, K. G. \& Minnaar, A., Functional properties of cowpeas (Vigna unguiculata L.Walp) flours and pastes as affected by $\gamma$-irradiation, Food Chemistry, 93 (1): 103111, Nov. 2005.

[26] Adejumo, B. A., Some Quality Attributes of Locally Produced Wheat Flour in Storage, Journal Of Environmental Science, Toxicology And Food Technology (IOSR-JESTFT), 5 (2), 47-49, 2013.

[27] Adebowale, Y. A., Adeyemi, I. A. \& Oshodi, A. A., Functional and physicochemical properties of flours of six Mucuna species, African Journal of Biotechnology, 4 (12), 1461-1468, Dec. 2005.

[28] Kinsella, J. E., Functional properties of soy protein, Journal of the American Oil Chemists' Society, 56, 254-264, Mar. 1979.

[29] Baah, F. D., Oduro, I. \& Ellis, W.O., Evaluation of the suitability of cassava and sweet potato flours for pasta production, Journal of Science and Technology, 25 (1), 16-24, June 2005.

[30] Plahar, W. A., Bediako-Amoa, B. \& Fejer, D., Functional properties of full-fat soy flour from soybeans grown in Ghana: Emulsifying properties, Ghana Journal of Agricultural Science, 10, 79-83, Mar. 1977. 